\title{
ADAMTS-13 gene expression in antiphospholipid syndrome
}

Antifosfolipid sendromunda ADAMTS-13 gen ekspresyonu

\author{
Veysel Sabri Hançer ${ }^{1}$, Reyhan Diz Küçükkaya ${ }^{2}$, Ayşegül Topal-Sarıkaya ${ }^{3}$ \\ ${ }^{1}$ Department of Medical Biology and Genetics, Faculty of Medicine, İstanbul Bilim University, İstanbul, Turkey \\ ${ }^{2}$ Department of Internal Medicine, Division of Hematology, Faculty of Medicine, Istanbul Bilim University, İstanbul, Turkey \\ ${ }^{3}$ Department of Molecular Biology and Genetics, Faculty of Science, Istanbul University, Istanbul, Turkey
}

\begin{abstract}
Antiphospholipid syndrome (APS) is an autoimmune disorder characterized by recurrent thrombosis and fetal mortality. Thrombotic microangiopathy (TMA) is an important histological finding in catastrophic APS (CAPS) and in APS patients with nephropathy. Analysis of familial thrombotic thrombocytopenic purpura patients showed that there are mutations in the ADAMTS-13 gene that lead to functional defects in the ADAMTS-13 enzyme. The aim of this study was to investigate the prevalence of the aforementioned mutations in APS, as well as to evaluate the level and activity of the ADAMTS-13 enzyme in patients with APS. C365del, Q449stop codon, P475S, and C508Y mutations were analyzed in APS patients. Transcriptions were analyzed using real-time PCR, and the level and activity of ADAMTS-13 were analyzed via fluorogenic assay. None of the mutations tested were present in the patient or control groups. The level of ADAMTS-13 mRNA in the patient group was $50 \%$ lower than that in the control group. Although a significant difference in ADAMTS-13 activity was not observed between the patient and control groups, a significant association was observed with the level of ADAMTS-13 $(p<0.0001)$. The level and activity of ADAMTS-13 were not associated with thrombotic complications, thrombocytopenia, or pregnancy complications in the patients with APS.
\end{abstract}

(Turk J Hematol 2011; 28: 213-8)

Key words: Antiphospholipid syndrome, ADAMTS-13, gene expression

Received: April 22, 2011

Accepted: April 28, 2011

Özet

Antifosfolipid sendrom (AFS), tekrarlayan tromboz ve fetal kayılar ile karakterize olan otoimmün bir hastalıktır. Trombotik mikroanjiyopati (TMA), katastrofik AFS ve nefropatinin eşlik ettiği AFS olgularında önemli bir histolojik bulgudur. Ailesel trombotik trombositopenik purpura olgularının incelenmesi sonucu, ADAMTS-13 enziminin işlev bozukluğuna yol açan mutasyonların varlığını göstermiştir. Bu çalışmada ADAMTS-13 mutasyonları ile, enzimin aktivite ve miktarının AFS'ye katkısının olup olmadığının araştırılması amaçlanmıştır. Bu kapsamda C365del, Q449stop kodonu, P475S ve C508Y mutasyonları analiz edildi. Transkripsiyon aşaması gerçek zamanlı polimeraz zincir reaksiyonu, enzimin aktivite ve miktarı ise florojenik bir yöntem ile incelendi. Varlı̆̆ı araştırılan mutasyonlar kontrol ve hasta gruplarında tespit edilmedi. ADAMTS-13 mRNA ve protein miktarmm hasta grubunda kontrol grubundaki düzeyin yarısı kadar olduğu saptandı. $(p<0.0001)$. Enzim aktivitesi açısından ise iki 
grup arasında istatistik olarak anlamlı bir fark gözlenmedi. Sonuç olarak, ADAMTS-13 enzim aktivitesi ve miktarının AFS hastalarında trombotik komplikasyonlar, trombositopeni ve gebelik komplikasyonları ile ilişkili olmadığı saptandı. (Turk J Hematol 2011; 28: 213-8)

Anahtar kelimeler: Antifosfolipid sendrom, ADAMTS-13, gen ekspresyonu.

\section{Introduction}

Antiphospholipid syndrome (APS) is characterized by both arterial and venous thrombosis, and fetal mortality in the presence of antiphospholipid antibodies (aPLAs) [1]. aPLA antibodies are directed against plasma proteins bound to anionic phospholipids [2]. Research has shown that aPLA-associated vascular lesions are predominantly noninflammatory vessel alterations with thrombotic luminal obliteration [2-6]. Thrombotic microangiopathy (TMA), which is histologically defined as the development of hyaline thrombi in small vessels, is a frequent finding in patients with thrombotic thrombocytopenic purpura (TTP) and hemolytic uremic syndrome (HUS).

TTP is a rare disorder caused by inhibition of or low-level ADAMTS-13 (a disintegrin-like metalloprotease with thrombospondin type-1 motif, member 13), an enzyme responsible for cleaving von Willebrand factor (vWF). vWF is a large, multidomain glycoprotein in human blood and secretory granules of both endothelial cells and platelets [7]. vWF circulates as a multimer and is composed of identical units that range in molecular weight from $500 \mathrm{kDa}$ to $>20,000 \mathrm{kDa}$. Immediately downstream of the site of injury the multimeric size of vWF is physiologically regulated to prevent the formation of thrombi. ADAMTS-13 cleaves vWF between Tyr842 and Met843 in the A2 domain of the vWF monomer [7-13], yielding typical fragments of 176 and $140 \mathrm{kDa}$, as well as smaller multimers.

Severe ADAMTS-13 deficiency may result in ultralarge vWF multimers that spontaneously interact with platelet receptors and cause thrombi in microcirculation [14-17]. Very low-level ADAMTS-13 activity ( $<5 \%$ of values in normal plasma), caused either by mutations of the ADAMTS-13 gene [10, 18-20] or inhibitory antibodies against ADAMTS-13 [15, 16], is linked to TTP/HUS. TMA is an important histological finding in patients with CAPS and in APS patients with nephropathy. The present study aimed to examine ADAMTS-13 level and activity, C365del, Q449stop, P475S, and C508Y mutations, and mRNA levels.

\section{Materials and Methods}

\section{Study population}

The study included 37 APS patients with thrombotic complications and 33 aPLA-positive patients without thrombotic complications, and 70 age- and sex-matched healthy controls. APS was diagnosed in patients with arterial and/or venous thrombosis based on the presence of lupus anticoagulant (LA) or anticardiolipin antibodies (ACA) [1]. All the healthy controls were Caucasian with a negative history of thrombosis and fetal mortality. The study protocol was approved by the Istanbul Bilim University, Faculty of Medicine Ethics Committee and written and signed informed consent was provided by all the participants.

\section{APS patients with thrombosis}

Of the 37 APS patients, 23 were female. LA was diagnosed based on activated partial thromboplastin time, kaolin clotting time, and Russell's viper venom test results, as previously reported [21]. The presence of IgG and IgM antibodies was determined via enzyme-linked immunosorbent assay (ELISA) [22], and levels $\geq 3$ standard deviations were regarded as positive. ACA and LA tests were repeated 2 months after the first test.

\section{aPLA-positive patients without thrombosis}

Among the 33 aPLA-positive patients without thrombosis, 28 were female. These patients had first trimester fetal mortality or thrombocytopenia, and persistently positive aPLA test results, but no thrombotic complications during $\geq 3$ years of follow-up. In all, 14 of the patients had thrombocytopenia, 7 had first trimester fetal mortality, and 12 had both thrombocytopenia and first trimester fetal mortality in the presence of aPLA (Table 1). None of the patients had clinical evidence of TMA events. 
Table 1. Characteristics of the APS patients and healthy controls

\begin{tabular}{|c|c|c|c|}
\hline $\begin{array}{r}\mathrm{AF} \\
\text { with }\end{array}$ & $\begin{array}{l}\text { PS patients } \\
\text { th thrombosis } \\
n=37\end{array}$ & $\begin{array}{l}\text { aPLA (+) patients } \\
\text { without thrombosis } \\
\qquad \mathrm{n}=33\end{array}$ & $\begin{array}{c}\text { Controls } \\
n=70\end{array}$ \\
\hline Female/male ratio & $23 / 14$ & $28 / 5$ & $51 / 19$ \\
\hline \multicolumn{4}{|l|}{ Age (years) } \\
\hline Median \pm SD & $37 \pm 2.2$ & $37 \pm 2.3$ & $39 \pm 4.2$ \\
\hline Range & $18-54$ & $22-56$ & $18-53$ \\
\hline \multicolumn{4}{|l|}{ Thrombosis, n (\%) } \\
\hline Arterial & $14(37.84)$ & 0 & 0 \\
\hline Venous & $19(51.35)$ & 0 & 0 \\
\hline $\begin{array}{l}\text { Arterial and } \\
\text { venous }\end{array}$ & $4(10.81)$ & 0 & 0 \\
\hline $\begin{array}{l}\text { Thrombocytopenia, } \\
\text { n (\%) }\end{array}$ & $6(16.22)$ & $14(42.42)$ & 0 \\
\hline Fetal losses, n (\%) & $11(29.73)$ & $7(21.21)$ & 0 \\
\hline $\begin{array}{l}\text { Thrombocytopenia } \\
\text { and fetal mortality, } \\
\text { n (\%) }\end{array}$ & 0 & $12(36.36)$ & 0 \\
\hline \multicolumn{4}{|c|}{$\begin{array}{l}\text { Presence of anticardiolipin antibodies } \\
\text { (\% of the involved group) }\end{array}$} \\
\hline IgG & 39.3 & 60 & negative \\
\hline IgM & 47.8 & 46.6 & negative \\
\hline Lupus anticoagulan & nt 80 & 86.6 & negative \\
\hline Mean Ct (mRNA level) & l) 0.36 & 0.38 & 0.77 \\
\hline $\begin{array}{l}\text { ADAMTS-13 } \\
\text { antigen (\%) }\end{array}$ & 66.63 & 63.39 & 98.2 \\
\hline $\begin{array}{l}\text { ADAMTS-13 } \\
\text { activity (\%) }\end{array}$ & 88.39 & 92.91 & 92.72 \\
\hline
\end{tabular}

APS: Antiphospholipid syndrome; aPLA: antiphospholipid antibodiesi IgM: Immunoglobulin M; IgG: immunoglobulin G; mRNA: messenger ribonucleic acid; ADAMTS-13: A disintegrin and metalloproteinase with a thrombospondin type 1 motif, member 13; Ct: cycle threshold

\section{Genotyping}

Genomic DNA was extracted from venous blood samples using a High Pure PCR Template Preparation Kit (Roche Diagnostics, IN, USA). DNA was amplified via polymerase chain reaction (PCR) using $100 \mathrm{ng}$ of DNA, $200 \mathrm{nM}$ of each primer, $200 \mu \mathrm{M}$ of each dNTP, $1.0 \mu \mathrm{M}$ of $\mathrm{MgCl}_{2}$, and 1.5 $\mathrm{U}$ of Taq DNA polymerase for 35 cycles in order to analyze mutations. PCR products were digested with restriction enzymes for C365del, Q449stop, and P475S (Table 2). For the C508Y mutation, PCR products were directly sequenced using an $\mathrm{ABI} 310$ genetic analyzer (Applied Biosystems, Foster City, CA, USA).

\section{Quantification of ADAMTS-13 transcripts}

Total RNA was extracted from venous blood samples using the RNA Preparation Kit (Roche Diagnostics, IN, USA). cDNA was obtained from total RNA using the RevertAid First Strand cDNA Synthesis Kit (MBI-Fermentas, St. Leon-Rot, Germany). The target gene (ADAMTS-13) and a reference gene (HPRT1) were analyzed via real-time PCR using a LightCycler 2.0 (Roche Diagnostics, Mannheim, Germany).

\section{Activity and antigen levels}

ADAMTS-13 activity and antigen levels were simultaneously measured in the same sample via fluorogenic assay (Technozym ADAMTS-13, Technoclone, Wien, Austria). Fluorescence was measured at 360/460 $\mathrm{nm}$ with a spectrofluorometer (Biotek reader FLX 800, Austria).

\section{Statistical analysis}

The t-test was used to analyze associations between quantitative data and a $\mathrm{p}$ value $<0.05$ was considered statistically significant. Correlations were investigated using Spearman's rank test. All calculations were performed using Graph-PAD Instat v.3.06 (GraphPad software Inc., San Diego, CA, USA).

\section{Results}

\section{ADAMTS-13 mutations}

C365del, Q449stop, P475S, and C508Y ADAMTS-13 mutations, which were previously reported to affect ADAMTS-13 activity, were investigated. None of these mutations were noted in the patient or control groups. In order to determine if these nucleotide changes are polymorphic, an additional 250 healthy Turkish individuals (female/male: 148/102) were genotyped, and none had the aforementioned mutations.

\section{ADAMTS-13 mRNA}

The level of ADAMTS-13 mRNA in the APS patients was $50 \%$ less than that in the control group, based on the Pfaffl equation [23], as follows:

$$
\begin{gathered}
\text { ratio } \left.=\left(\mathrm{E}_{\text {target }}\right) \Delta \mathrm{CP} \text { target (control-sample }\right) /\left(\mathrm{E}_{\text {reference }}\right) \\
\begin{array}{c}
\Delta \mathrm{CP} \text { reference } \\
\text { ratio }
\end{array}=1,978^{-1,48 / 1,964^{-0,38}=0.5}
\end{gathered}
$$


Table 2. Primer sequences, probes, and restriction enzymes

\begin{tabular}{|c|c|c|c|}
\hline Exon number, Primer name & Primer sequence & PCR product (bp) & Enzyme \\
\hline $10+11$, C365del 1 & 5'GGGATCCCTATGGGTGAGTT3' & 561 & Alw21I \\
\hline $10+11$, C365del 2 & 5'CCTGGTGTGAACCACAGATG 3' & 561 & Alw21I \\
\hline 12,Q449stop1 & 5'GTGCCATGTAGTCTCCCAGTGACAACACC3' & 327 & FspBI \\
\hline 12,Q449stop2 & 5'CCAGAGCCTGAACCACTTTGCCCAGTGC3' & 327 & FspBI \\
\hline $12, \mathrm{P} 475 \mathrm{~S} 1$ & 5'GTGCCATGTAGTCTCCCAGTGACAACACC3' & 327 & Eco130I \\
\hline $12, \mathrm{P} 475 \mathrm{~S} 2$ & 5'CCAGAGCCTGAACCACTTTGCCCAGTGC3' & 327 & Eco130I \\
\hline $13+14$, C508Y 1 & 5'CCCAGATGCAAAGGATGAAG3' & 839 & - \\
\hline $13+14, \mathrm{C} 508 \mathrm{Y} 2$ & 5'ATCCAGGGCTGAGTGAGTGT3' & 839 & - \\
\hline A-13 Forward & 5'AGTACAGAGTGGCCCTCACC3' & 106 & \\
\hline A-13 Reverse & 5'CCATACCGCCTGTAAACCTG3' & 106 & \\
\hline Probe & FAM-UPL Probe \#25 (Roche)-dark quencher & & \\
\hline HPRT1 Forward & 5'TGACCTTGATTTATTTTGCATACC3' & 102 & \\
\hline HPRT1 Reverse & 5'CGAGCAAGACGTTCAGTCT3' & 102 & \\
\hline Probe & FAM-UPL Probe \#73 (Roche)-dark quencher & & \\
\hline
\end{tabular}

\section{ADAMTS-13 antigen and activity}

Median ADAMTS-13 activity was 92.55\% (range: $62 \%-124 \%$ ) in the patient group and $92.72 \%$ (range: $68 \%-124 \%$ ) in the control group. ADAMTS-13 activity was $88.39 \%$ and $92.91 \%$ in the APS patients with and without a history of thrombosis, respectively, and although ADAMTS-13 activity was lower in the APS patients with thrombosis, the difference was not statistically significant (t-test, $\mathrm{p}=0.4369,95 \% \mathrm{CI}$ : 62.91-96.94). Median ADAMTS-13 antigen level was significantly lower $(64.88 \%)$ in the patient group (66.63\% in the APS patients with thrombosis and $63.39 \%$ in those without thrombosis) than in the control group (98.2\% [range: 55\%-159\%]) (t-test, $\mathrm{p}<0.0001,95 \%$ CI: 56.91-138.94). ADAMTS-13 activity in the control group was correlated with gender $(p=0.0038)$, but not with age. There wasn't a correlation between the level of ADAMTS-13 and its activity, and ADAMTS-13 activity varied in participants that had the same level of ADAMTS-13.

\section{Discussion}

The presence of neutralizing anti-ADAMTS-13 autoantibodies or mutations resulting in severe ADAMTS-13 deficiency is a well-known major cause of acquired and congenital TTP. ADAMTS-13 activity in TTP patients, however, is generally $<5 \%$ or $10 \%$. Amoura et al. reported 2 APS patients with unde- tectable ADAMTS-13 activity that developed TTP. They also investigated ADAMTS-13 activity in their APS cohort $(n=20)$, and observed that mean ADAMTS-13 activity was normal (116\%; range: 44\%$250 \%)$ and that none of the patients had severe ADAMTS-13 deficiency [24].

The literature contains only a few studies on antiADAMTS-13 antibodies and ADAMTS-13 activity in APS patients. Austin et al. [25] reported that 52 of 68 APS patients had IgG antibodies against ADAMTS-13 based on ELISA, and 22 patients had low-level ADAMTS-13 activity, although median ADAMTS-13 activity was $34 \%$. Rieger et al. reported that the prevalence of anti-ADAMTS-13 IgG and IgM antibodies among 55 APS patients was $5 \%$ and $18 \%$, respectively. ADAMTS-13 activity in APS patients ranged from $32 \%$ to $114 \%$, and there wasn't a correlation between autoantibody titers and ADAMTS-13 activity [26].

The present study has 2 limitations: the study population was small and although many mutations have been reported in TTP, only 4 previously reported to affect ADAMTS-13 activity were investigated; however, to the best of our knowledge this is the first study to investigate these 4 mutations in APS. The present study investigated mutations that affect ADAMTS-13 activity, mRNA level, and antigen level in APS patients with thrombosis, aPLA-positive patients without thrombosis, and healthy controls. Genotyping for ADAMTS-13 mutations (C365del, 
Q449stop codon, C508Y, and P475S) showed that none of the patients or controls carried these mutations. The present study's findings are the first to show that there isn't a relationship between ADAMTS-13 mutations and APS. ADAMTS-13 mRNA and antigen levels were lower in the patients than in the controls. This finding suggests that the ADAMTS-13 gene is negatively regulated during transcription, mutation/s may be present in the promoter region, or there may be an epigenetic effect. Although ADAMTS-13 activity was also low in the APS patients with thrombosis but, ADAMTS-13 activity did not reach statistical significance when compared with controls. ADAMTS-13 activity and level were not associated with thrombotic complications, thrombocytopenia, or pregnancy complications in the patients with APS.

\section{Acknowledgements}

This study was supported by the Istanbul University Research Fund (project no. 1454).

\section{Conflict of interest statement}

The authors of this paper have no conflicts of interest, including specific financial interests, relationships, and/or affiliations relevant to the subject matter or materials included.

\section{References}

1. Miyakis S, Lockshin MD, Atsumi T, Branch DW, Brey RL, Cervera R, Derksen RH, DE Groot PG, Koike T, Meroni PL, Reber G, ShoenfeldY, TincaniA, Vlachoyiannopoulos PG, Krilis SA. International consensus statement on an update of the classification criteria for definite antiphospholipid syndrome (APS). J Thromb Haemost 2006;4:295-306.

2. Salmon JE, de Groot PG. Pathogenic role of antiphospholipid antibodies. Lupus 2008;17:405-11.

3. Levine JS, Branch DW, Rauch J. The antiphospholipid syndrome. N Engl J Med 2002;346:752-63.

4. Nimmo MC, Carter CJ. The antiphospholipid antibody syndrome: a riddle wrapped in a mystery inside an enigma. Clin Appl Immunol Rev 2003;4:125-40.

5. Lockshin MD, Erkan D. Treatment of antiphospholipid syndrome. N Engl J Med 2003;349:1177-9.

6. Diz-Kucukkaya R. Thrombosis in the antiphospholipid syndrome. Turk J Hematol 2006;2:5-14.

7. Moake JL, Turner NA, Stathopoulos NA, Nolasco LH, Hellums JD. Involvement of large plasma von Willebrand factor (vWF) multimers and unusually large vWF forms derived from endothelial cells in shear stress-induced platelet aggregation. J Clin Invest 1986;78:1456-61.
8. Furlan M, Robles R, Lämmle B. Partial purification and characterization of a protease from human plasma cleaving von Willebrand factor to fragments produced by in vivo proteolysis. Blood 1996;87:4223-34.

9. Tsai HM. Physiologic cleavage of von Willebrand factor by a plasma protease is dependent on its conformation and requires calcium ion. Blood 1996;87:4235-44.

10. Levy GG, Nichols WC, Lian EC, Foroud T, McClintick JN, McGee BM, Yang AY, Siemieniak DR, Stark KR, Gruppo R, Sarode R, Shurin SB, Chandrasekaran V, Stabler SP, Sabio H, Bouhassira EE, Upshaw JD Jr, Ginsburg D, Tsai HM. Mutations in a member of the ADAMTS gene family cause thrombotic thrombocytopenic purpura. Nature 2001;413:488-94.

11. Soejima $\mathrm{K}$, Mimura $\mathrm{N}$, Hirashima $\mathrm{M}$, Maeda $\mathrm{H}$, Hamamoto T, Nakagaki T, Nozaki C. A novel human metalloprotease synthesized in the liver and secreted into the blood: possibly, the von Willebrand factorcleaving protease?. J Biochem 2001;130:475-80.

12. Cal S, Obaya AJ, Llamazares M, Garabaya C, Quesada V, López-Otín C. Cloning, expression analysis, and structural characterization of seven novel human ADAMTSs, a family of metalloproteinases with disintegrin and thrombospondin- 1 domains. Gene 2002;283:49-62.

13. Dent JA, Berkowitz SD, Ware J, Kasper CK, Ruggeri ZM. Identification of a cleavage site directing the immunochemical detection of molecular abnormalities in type IIA von Willebrand factor. Proc Natl Acad Sci U.S.A. 1990;87:6306-10.

14. Manea M, Kristoffersson A, Tsai HM, Zhou W, Winqvist I, Oldaeus G, Billström R, Björk P, Holmberg L, Karpman D. ADAMTS13 phenotype in plasma from normal individuals and patients with thrombotic thrombocytopenic purpura. Eur J Pediatr 2007;166:249-57.

15. Veyradier A, Obert B, Haddad E, Cloarec S, Nivet H, Foulard M, Lesure F, Delattre P, Lakhdari M, Meyer D, Girma JP, Loirat C. Severe deficiency of the specific von Willebrand factor-cleaving protease (ADAMTS 13) activity in a subgroup of children with atypical hemolytic uremic syndrome. J Pediatr 2003;142:310-7.

16. Scully M, Cohen H, Cavenagh J, Benjamin S, Starke R, Killick S, Mackie I, Machin SJ. Remission in acute refractory and relapsing thrombotic thrombocytopenic purpura following rituximab is associated with a reduction in IgG antibodies to ADAMTS-13. Br J Haematol 2007;136:451-61.

17. Plaimauer B, Zimmermann K, Volkel D, Antoine G, Kerschbaumer R, Jenab P, Furlan M, Gerritsen H, Lämmle B, Schwarz HP, Scheiflinger F. Cloning, expression, and functional characterization of the von Willebrand factor-cleaving protease (ADAMTS13). Blood 2002;100:3626-32.

18. Pimanda JE, Maekawa A, Wind T, Paxton J, Chesterman $\mathrm{CN}$, Hogg PJ. Congenital thrombotic thrombocytopenic purpura in association with a mutation in the second CUB domain of ADAMTS13. Blood 2004;103:627-9.

19. Veyradier A, Lavergne JM, Ribba AS, Obert B, Loirat C, Meyer D, Girma JP. Ten candidate ADAMTS13 mutations in six French families with congenital thrombotic 
thrombocytopenic purpura (Upshaw Schulman syndrome). J Thromb Haemost 2004;2:424-9.

20. Tao Z, Anthony K, Peng Y, Choi H, Nolasco L, Rice L, Moake JL, Dong JF. Novel ADAMTS-13 mutations in an adult with delayed onset thrombotic thrombocytopenic purpura. J Thromb Haemost 2006;4:1931-35.

21. Pengo V, Tripodi A, Reber G, Rand JH, Ortel TL, Galli M, De Groot PG. Update of the guidelines for lupus anticoagulant detection. Subcommittee on Lupus Anticoagulant/Antiphospholipid Antibody of the Scientific and Standardisation Committee of the International Society on Thrombosis and Haemostasis. J Thromb Haemost 2009;7:1737-40.

22. Harris EN. Antiphospholipid antibodies. Br J Haematol 1990;74:1-9.

23. Pfaffl MW. A new mathematical model for relative quantification in real-time RT-PCR. Nucleic Acids Res 2001;29:e45.
24. Amoura Z, Costedoat-Chalumeau N, Veyradier A, Wolf M, Ghillani-Dalbin P, Cacoub P, Meyer D, Piette JC. Thrombotic thrombocytopenic purpura with severe ADAMTS-13 deficiency in two patients with primary antiphospholipid syndrome. Arthritis Rheum 2004;50:3260-4.

25. Austin SK, Starke RD, Lawrie AS, Cohen H, Machin SJ, Mackie IJ. The VWF/ADAMTS13 axis in the antiphospholipid syndrome: ADAMTS13 antibodies and ADAMTS13 dysfunction. $\mathrm{Br} \mathrm{J}$ Haematol 2008;141:536-44.

26. Rieger M, Mannucci PM, Kremer Hovinga JA, Herzog A, Gerstenbauer G, Konetschny C, Zimmermann K, Scharrer I, Peyvandi F, Galbusera M, Remuzzi G, Böhm M, Plaimauer B, Lämmle B, Scheiflinger F. ADAMTS13 autoantibodies in patients with thrombotic microangiopathies and other immunomediated diseases. Blood 2005;106:1262-7. 